\title{
'Made in China'
}

\section{An emerging brand in the global arms market}

Authors:

Dr Ling Li, Wuhan Military Economy Academy, People's Republic of China, and Professor Ron Matthews, Cranfield University, Defence Academy of the United Kingdom, Shrivenham SN6 8LA.

Corresponding author:

Professor Ron Matthews:

e-mail address: r.g.matthews@ cranfield.ac.uk

Tel: 0044 (0)1793 785653 


\title{
'Made in China' \\ An emerging brand in the global arms market
}

\begin{abstract}
:
Possession of a brand is a sine qua non for economic success, not least because it connotes trust in delivering the value promised. Successful brands are not isolated to commercial endeavor but apply equally to defense. Although Western, especially American, Original Equipment Manufacturers, offer branded systems whose sales are influenced by price, there are also a plethora of other non-price variables, such as client-state relations, technology offset requirements, life-cycle costs and strategic trade controls. New entrants to the international arms market will struggle in the absence of such arms 'packages'. China's entry into the international arms market, however, is an exception to this rule, and it is the aim of this paper to chart the country's progress in establishing an international brand. The starting point is to profile China's arms exporting experience through a four-stage historical model, providing the contextual backdrop for identifying the distinctive drivers that have forged market entry into 55 countries worldwide. The export strategy employed initially focused on promoting sales of rudimentary military equipment for political purposes, but more recently has sought growth through commercializing exports, repositioning them from a low- to a high-tech foreign sales trajectory. In the process, a Sino 'brand' is emerging, reflecting traditional competitiveness attributes and contemporary diplomatic considerations, especially non-interference in client state domestic affairs.
\end{abstract}

Key words: China; arms exports; economic diplomacy; growth strategy; arms controls. 


\section{Introduction}

The development of China's defense industry since the Second World War offers a remarkable case study of industrial transformation against all odds. Since the 1950s, the country has been convulsed by numerous politico-economic disasters, dramatically impacting on the pace and progression of industrial change. Such obstacles to development included early expulsion of Soviet engineers and the termination of access to weapons and technology from the USSR. This was followed in the 1960s by Mao Tse-Tung's hugely disruptive policies, leading to curtailment of economic growth, employment and industrial expansion. This stultifying economic performance continued for another two decades, primarily because communist China was mired in endemic bureaucratic and innovational inefficiencies associated with the dead economic hand of Marxism. Finally, following the 1989 Tiananmen Square incident, China suffered from the West's imposition of an arms embargo.

Yet, China has overcome all these obstacles to craft a modern defense sector that is impressive both in terms of its breadth and depth of military capability. Whilst there is a debate on how close China is to becoming a truly $1^{\text {st }}$-tier defense industrial power, there is no denying the immense technological leap it has already achieved across the entire capability spectrum. ${ }^{1}$ Such increases in capability, and also competitiveness, can be gauged by export performance. In this regard, China's arms exports expanded 6.5 times between 2000 and $2015,{ }^{2}$ and it is now regularly ranked amongst the world's top arms exporters (see Table 1). Although China's share of global arms exports was just $6.9 \%$ in 2015, and well below America's $36.6 \%$ share, this was nevertheless 2.5 times greater than its 2001 share. ${ }^{3}$ Moreover, unlike the US, China does not export arms to the advanced countries. The process of moving up the technology ladder has only just begun, and while systems integration of combat systems is occurring, $1^{\text {st }}$-tier defense-industrial status remains a goal. ${ }^{4}$ China's restrained industrial status has inevitably led to a $2^{\text {nd }}$ order strategic mapping of less sophisticated military systems to lower income countries. This is reflected by data published in the 2016 Military Balance by the London-based International Institute for Strategic Studies that highlights Chinese military equipment is now used by more than two-thirds of African countries, "reflecting the broader growth in Beijing's influence and investment in the continent". 5 
Table 1: World's top 10 arms exporters, selected years

\begin{tabular}{|ll|l|l|l|l|}
\hline \multicolumn{2}{|l|}{ Rank 2013 } & Supplier & 2013 & 2014 & 2015 \\
\hline 1 & $(1)$ & United States & 7687 & 10470 & 10484 \\
\hline 2 & $(2)$ & Russia & 8107 & 5468 & 5483 \\
\hline 3 & $(5)$ & China & 2055 & 1360 & 1966 \\
\hline 4 & $(4)$ & France & 1511 & 1734 & 2013 \\
\hline 5 & $(3)$ & Germany (FRG) & 722 & 1785 & 2049 \\
\hline 6 & $(7)$ & United Kingdom & 1645 & 1644 & 1214 \\
\hline 7 & $(6)$ & Spain & 732 & 1062 & 1279 \\
\hline 8 & $(9)$ & Italy & 867 & 743 & 570 \\
\hline 9 & $(10)$ & Ukraine & 689 & 657 & 323 \\
\hline 10 & $(8)$ & Israel & 414 & 400 & 710 \\
\hline
\end{tabular}

Source: Data sourced from the SIPRI Arms Transfers Database, based on US \$m at constant (1990) prices (accessed 20 July, 2016). NB: 2015 rankings in parenthesis.

Foreign policy issues are believed to weigh heavily on China's arms export strategy. There is a long-standing Western school of thought that argues China's arms sales to the developing world are considerably influenced by regional military situations; ${ }^{6}$ that China's engagement in, for instance, Africa's economy as well as acting as an arms supplier, undermines Western efforts to spread democracy and prosperity. ${ }^{7}$ Yet, there is another school of thought that takes a more benign view regarding the impact of China's arms sales. Indra de Soysa et al (2012), ${ }^{8}$ for instance, constructed an empirical model using 1989-2006 data to compare the political effect of US versus Chinese arms exports to sub-Saharan Africa. Their findings indicate, controversially, that... "Chinese arms transfers, particularly in Sub-Saharan Africa, are made in larger amounts to countries that respect the physical integrity rights of people as well as to countries higher on a scale of democracy than transfers made by the United States, which seems to prefer the security of autocracies." 9

The growth in Chinese weapons sales begs the question as to the source of this demand. The less than novel response is that China exports to all those states that the West does not. At least this has been the putative model, but circumstances are now changing. China is beginning to penetrate markets that are traditionally client states of both the West and Russia, including Indonesia and Nigeria. Moreover, a parallel trend 
of some significance is that whilst 43 of Beijing's customers are concentrated in the developing countries of Asia, Africa and South America, there are now 14 states belonging to the upper middle/higher income country categories. ${ }^{10}$

The purpose of this paper, then, is to evaluate the reasons behind China's remarkable arms export performance, particularly the historical antecedents, global strategy, evolving market structure and finally the attributes defining China's successful arms 'paradigm'. The topic has policy significance because the emergence of a Chinese armaments 'brand' will not only erode the pre-eminent market positions of traditional arms suppliers, but, as an important element in soft-power relations between countries, China's rising arms exports will inevitably degrade the strategic influence presently enjoyed by Western actors.

\section{China's defense export performance ${ }^{11}$}

There is no record of Chinese arms exports during the late $19^{\text {th }}$ century, most likely because throughout this early stage of defense industrialization all output would have been channeled to satisfy internal demand. These conditions extended into the $20^{\text {th }}$ century, especially following the end of Qing Dynasty in 1911 when China became embroiled in a multitude of hugely destructive conflicts, including civil war, internecine disputes between warlords, the bloody Sino-Japanese conflagration between 1937 and 1945, and finally the war between China's Communist forces and the Kuomintang from 1945 to 1949. During this latter period, local defense firms were unable to cope with the massive and sustained increase in arms demand, and, sporadically, American and Soviet military aid filled the procurement gap. Due to this prolonged period of military turbulence, China was unable to export armaments until the 1950s, and by that stage, the People's Republic of China was a fully signed-up member of the Communist Bloc, enjoying substantial inward transfers of Soviet military materials, including weapons, production equipment and technical support.

Figure 1 shows the value of China's arms exports across the 60-year period, 
1954-2015. China's post-WWII export trend is characterized by major fluctuations caused by significant politico-economic and military events. Arms sales reached their post war peak in 1988, fueled by the Vietnam conflict. Thereafter, there was a steady decline in exports until 2005. Sales then surged until 2013, when Chinese arms exports were ranked third biggest in the world. Across the entire 60-year period, there

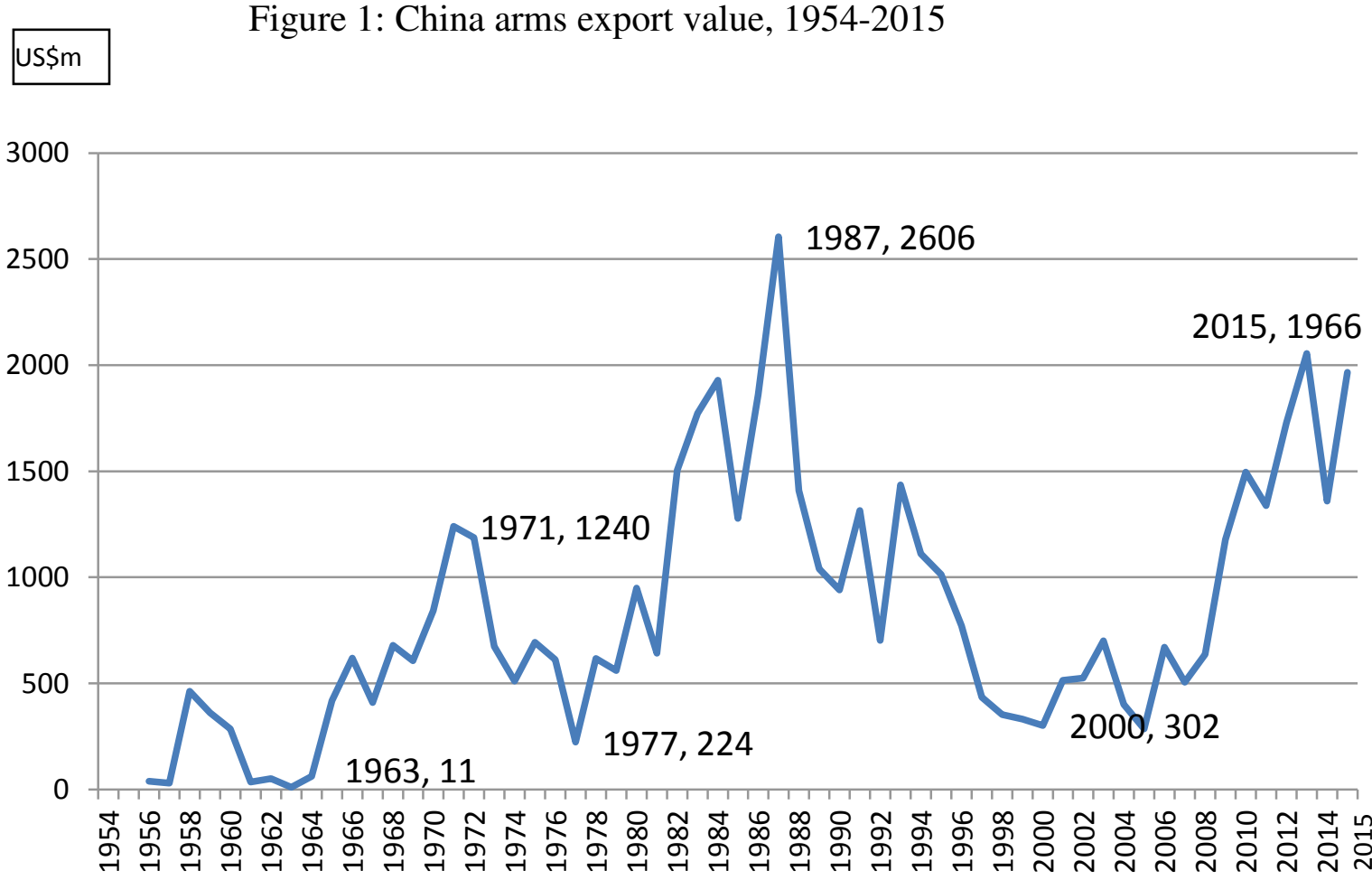

Total Arms Exports From China

Source: Data sourced from SIPRI International Arms Transfer Database, expressed in US\$m at constant (1990) prices (accessed 26 July, 2016).

are four distinct arms export stages, and each of these will now be identified and explained, below.

\section{-Stage 1: the Mao era - 1954 to 1976}

China's earliest arms exports were to Vietnam during the First Indo-China War (1950-54) when the Vietnamese sought to oust French colonial forces. These exports consisted of small arms and basic military equipment, and in 1954 amounted to some 
US\$3 million (1990 constant prices). However, this was 'friendship' trade, undertaken for ideological reasons, to support fellow fledgling communist states. ${ }^{12}$ China's other neighboring state, North Korea, was also engaged in a patriotic independence struggle, and would similarly have received China's arms exports free of charge through the receipt of direct grants. Indeed, prior to 1978 most Chinese arms transfers to other countries was in the form of military aid. ${ }^{13}$ However, such concessionary exports were not a costless exercise, and were occurring at a time when the ruinous impact of the Cultural Revolution was dramatically shrinking the Chinese economy.

The first surge in China's arms exports occurred between 1963 and 1970. It was partially supply-driven through the additional capacity generated by the infusion and imitation of Soviet military technology imported during the 1950s. Major Asian conflicts were also an important contributory factor behind the rise in Chinese arms exports, including the 1965 Indo-Pak War, the continuing tensions along the $38^{\text {th }}$ Parallel fueling an insatiable North Korean demand for weaponry, and the Second Indo-China War (1963-75) between Vietnam and the US. Although the Vietnam War raged until 1975, China's arms exports declined during this decade. This reflected Beijing's distraction from external affairs as a result of the ongoing internal cataclysmic events arising from the 1966-76 Cultural Revolution.

During the Mao era, three Asian countries accounted for the lion's share of China's arms sales: Pakistan, ranked first, taking 26.7\%; North Korea, second, with 25.9\%; and finally North Vietnam accounting for $11.7 \%$. China also supported East European Communist states, with Albania accounting for $18.8 \%$ of Beijing's arms sales and Romania $4.4 \%$. Additionally, some $2.7 \%$ of China's arms sales found their way to Tanzania in Africa, with the remainder taken by a motley group of states, including Egypt, Sudan, the Democratic Republic of Congo and Cambodia. 
China began its reform policy, including trade liberalization, in 1978, and the greater commercial edge that Deng applied to arms trading activities sounded the death-knell to Mao's paternalistic arms exports approach. The reforms impacted on the performance of both commercial enterprises and state-owned monolithic defense manufacturers; the latter, heretically, were required to be good capitalists, and maximize profits, shared between themselves and government. This focus on commercialism led to a second more aggressive upward trend in Chinese arms exports in the 1980s, initiated by the first arms-for-cash sales of military equipment to Egypt. ${ }^{14}$ By 1987, the value of China's arms exports had risen to around US\$ 2.6 billion (1990 constant prices). The huge increase in China's arm exports in the 1980s was due to the emergence of two powerful forces, one supply-driven - the institutional encouragement given to the arms factories to penetrate overseas markets in search for profit, and the other demand-driven - the high levels of arms demand caused by the Iraq-Iran War and North Korea's incessant sabre rattling at its Southern neighbor.

\section{-Stage 3: decade of consolidation - 1990 to 1999}

In the 1990s, China sought to consolidate its customer base, focusing primarily on markets in Asia and the Middle East, but this initiative came at a difficult time. The poor showing of Saddam Hussein's forces during the 1991 Gulf War was partly attributed to Iraq's inventory of Soviet weapon systems. America's Revolution in Military Affairs had rendered Soviet arms and doctrine obsolete, and this was bad news for China as its arms production was also based on geriatric Soviet designed weapons and outdated doctrine. As a result, Chinese arms almost overnight became less attractive, hampering marketing campaigns. Amongst the top 10 states continuing to import Chinese systems in the 1990s, Pakistan was first ranked, taking 29.3\%, of a reduced global market; Myanmar was ranked $2^{\text {nd }}$, with $18.9 \%$, having increased dramatically from a base of just $0.2 \%$ in the 1980s; Iran was ranked third with $17 \%$ and Thailand fourth, with $12.9 \%$, compared to almost zero a decade earlier. 
At the beginning of the 2000 s, China took just $1.67 \%$ of the international weapon exports market, while in 2015 its share had climbed to $6.87 \%$. Overseas sales peaked in 2013, when China exported arms worth US\$2,055m, to become the world's third biggest arms exporter. The following year, the country's ranking slipped to fifth, and a year later to sixth. However, arms sales are notoriously unpredictable, and taking one year's figures will not reflect the true picture. A more accurate assessment of arms export performance can be had by taking five-year moving averages of arms sales, and for China this would show a robust trajectory since 2000, accelerating dramatically from 2008 through to 2015. Indeed, across the period 2011-2015, China was the world's third biggest arms exporter behind the US and Russia. ${ }^{15}$ China exported arms to 55 countries, with the 'South' developing states taking the lion's share, and Asia, in particular, accounting for around $70 \%$ of total arms export value. This begs the question as to why Chinese arms have become so popular?

\section{Allure of Chinese Armaments}

There is no single factor behind the surge in China's arms exports, but rather a spectrum of reasons. Foremost amongst these is the importance of government policies to promote foreign arms sales. All China's key defense industrial players are state-controlled, so the linkage between arms exports and government policy is undeniable. As in the West, Chinese defense companies must obtain government authorization before export deals can be signed. The government's decision will be based on political, diplomatic and geo-strategic considerations, as well as transferee technology transfer requirements. Beijing, however, supports arms sales, and whilst its motivations are multifaceted, China does not view arms exports as primarily a commercial enterprise, with profit acting as the principal driver. Clearly, overseas sales will act to amortize the fixed costs of Chinese arms factories, but given the huge domestic procurement scale, the notion that arms exports are needed to defray expensive R\&D investment hardly seems plausible. Economics is important, but only as part of a broader soft power strategy aimed at strengthening China's influence overseas, especially amongst developing countries.

China's foreign policy includes weapons sales as a form of Chinese economic diplomacy. This is a more narrowly focused soft power framework, embracing foreign 
aid, foreign direct investment, training and educational programs, and arms exports. The latter 'model' is pre-determined and operates according to a carefully crafted strategy based on three principles: (1) promoting the legitimate self-defence capability of the recipient country; (2) strengthening the peace, security and stability of that country and region; and (3) non-interference in its internal affairs. ${ }^{16}$ The roots of China's economic diplomacy model go back to its 2001 'Going-Out' (Zou Chuqu) strategy that covered not only commercial but also defense-related export and investment. Since that time, Beijing has repeatedly emphasized the significance of adopting an outward perspective. A microcosm of this approach can be found in Section Four of China's 2006 African Policy on Peace and security, aimed at promoting "high-level military exchanges between the two sides and actively carrying out military-related technological exchanges and cooperation."17 The message was reinforced a year later when $\mathrm{Hu}$ Jingtao delivered a speech at the $17^{\text {th }}$ Congress of China's Communist Party, arguing...

"China is committed to developing friendship and cooperation with all other countries on the basis of the Five Principles of Peaceful Coexistence. ${ }^{18}$ We will also continue to conduct exchanges and cooperation with the political parties and organizations of other countries, and strengthen the external exchanges of people's congresses, CPPCC committees, the armed forces, localities and people's organizations to enhance mutual understanding and friendship between the Chinese people and the people of other countries." 19

From a security perspective, therefore, Chinese arms exports strengthen client-state relationships, and bolster Beijing's influence, particularly amongst contiguous states. It is no accident that China's arms sales to Pakistan, Sri Lanka, Bangladesh and Myanmar have carried the important additional impact of containing the emerging threat of Asia's other mega-power, India.

Another significant push factor is China's 'over-supply' of many types of consumption and capital goods, including weapons production. The problem of surplus capacity arose after 2007, coinciding with Asia-Pacific's economic and financial crisis. Since that time, the State Council has increasingly emphasised the 
importance of bolstering exports as a partial panacea to China's surplus domestic output. $^{20}$

There is also the notion of directed supply, whereby China's arms sales are targeted at those states possessing energy and natural resources. Energy is a critical ingredient for feeding the rapacious appetite of China's growing economy and ensuring social order and political stability are maintained. ${ }^{21}$ Blank (2009) employed an econometric model to test whether China might, indeed, be targeting its arms exports on resource-rich states in the hope of securing access to energy and raw materials. His findings suggest that "China displays unique patterns of arms exports and investment for oil and non-oil countries... [but] ... China's need for natural resources not its desire to counterbalance military production costs, encourages it to selectively transfer arms to states that are potential suppliers of energy assets." 22

Aside from these supply-driven 'push' forces, there are also numerous demand-side 'pull' factors promoting the growth of China's arms sales. The most important of these is undoubtedly Beijing's 'no-questions asked' approach to arms sales. Its long-standing non-interference diplomacy rests on the view that a customer's political, military and human rights record lies outside the arms deal's contractual arrangements. Although the policy has been described by one Chinese observer as just a "normal phenomenon", ${ }^{23}$ in the West it is controversial and the target of much criticism. Elsewhere, the reality on the ground is that the non-interference policy is welcomed. Good numbers of African countries, ${ }^{24}$ as well as pariah states, such as Iran and North Korea, turn to China as an arms supplier of last resort. ${ }^{25}$ The non-interference policy also operates as a magnate to other $2^{\text {nd }}$ and $3^{\text {rd }}$ tier military states suffering excessive dependence on American or Russian weaponry. Chinese arms provide the opportunity to diversify their arms supply and regain a degree of sovereignty over military capability. ${ }^{26}$ Procurement of Chinese military equipment, therefore, is increasingly viewed by developing states as a means of reducing the strategic vulnerability to arms embargoes, as has regularly been faced by Pakistan (1965, 1971 and 1979), and also by Indonesia (1999). 
Aside from political inducements, the harsh market reality is that Chinese-made weapons must compete with those of Russian and Western defense exporters. China has learned quickly that the international arms market is fiercely competitive, and whilst 'Made in China' is not yet a global brand, as a new entrant to the arms market its principal impact has come through competitive pricing, due principally to low costs. $^{27}$ One recent report suggests that China's average labour cost is around $19 \%$ of that prevailing in the UK, and $17 \%$ of the US. ${ }^{28}$ It is therefore unsurprising that a Chinese drone is less than a quarter of the cost of a US version, ${ }^{29}$ and the price of a Chinese F7 fighter is around a tenth of an American F16. ${ }^{30}$ Similarly, China's MBT-3000 boasts one fewer operator than General Dynamics' latest Abrams tank, and costs almost $\$ 2.9$ million less. ${ }^{31}$ Money matters in the international arms bazaar.

Low prices are obviously attractive to low income nations that suffer constrained procurement budgets. Yet just as important, China's product 'surround' invariably comprises generous financing options for weapon systems that offer ease of use, rising reliability, enhanced performance and low life cycle costs of maintainability, repair and overhaul. ${ }^{32}$ The appeal of Chinese arms to low-income nations is obvious, but, in an economically stressed world, China's arms deals are becoming increasingly attractive to middle-income states, such as Saudi Arabia, Oman, Jordan and Mexico. Combine technological appropriateness with competitive pricing, then, Chinese military equipment becomes even more appealing. This is evidenced by Turkey's surprise 2013 selection of a Chinese air and missile defense system rather than American, Russian or Italian-French offerings. A major consideration influencing Istanbul's decision was China's relatively low $\$ 3.4$ billion bid price, reportedly far lower than either the Russian or US bids. ${ }^{33}$ Although Chinese weapon systems are less reliable than US and Russian systems, and lacks compatibility with NATO equipment, ${ }^{34}$ the quality was deemed adequate for Turkey's requirements. ${ }^{35}$

China has also sold satellite jamming and cyber warfare capabilities to North Korea and Iran, ${ }^{36}$ and since 2011 it has reportedly sold the armed drone, Wing Loong, to several countries in African and Middle Eastern states, including Nigeria, Egypt and 
the United Arab Emirates. ${ }^{37}$ The Chinese are also keen to export their Pterodactyl drone to the United Arab Emirates, Saudi Arabia, and Uzbekistan. ${ }^{38}$ All three countries are oil exporters, and the collapse of the international oil price means that China's unmanned aircraft are particularly attractive, given that the price tag is just $10-20 \%$ of the US\$ 1million cost of comparative US Predator models. ${ }^{39}$ China's higher tech arms exports have also begun to penetrate the Latin American market, overcoming Russian competition to secure sales contracts of radar equipment to Venezuela and Ecuador. ${ }^{40}$ Competitive pricing was a key factor in these countries' procurement decisions, given that the Chinese systems were reportedly held to be "technically attractive enough". ${ }^{41}$ China's emerging role in the international arms market thus offers an early portent to established Western defence exporters. Indeed, it has prompted one leading EADS official to predict that... "China will be competing with us in many, many domains, and [at] the high end."42

The growth in China's technological capability is already happening, and, as a lever to bolster sales, it appears sympathetic to the idea of sharing that capability. Reportedly, the Chinese offer easier access to technology transfer compared to the limited opportunities available from Western or Russian suppliers. ${ }^{43}$ Importantly, China acts to support client countries in their efforts to indigenize maintenance, repair and overhaul activities, and even component production. It is difficult to determine the extent to which defense offset pressures have forced China to transfer technology, but there is no doubt that the attractiveness of offset packages has become a key criterion in the down-selection of bidders. Indeed, there is fragmentary evidence, as discussed below, that Beijing is cognizant of this fact, and views offset as an opportunist vehicle to lock client states into long-term defense industrial and technology partnerships.

\section{China's technological leap: from emulation to export}

Technology transfer represents the most important variable within an offset package, and normally includes design, blueprints, skills and manufacturing capability. Thus, when China procured several hundred Russian SU-27SK aircraft, licensed production 
was agreed, providing the opportunity for the Chinese to emulate advanced systems; a euphemism for reverse engineering. This is not sporadic exercise, but systematic, to the point where it has become embedded in China's technology development model. For instance, the Chinese defense company NORINCO recently unveiled a $55 \mathrm{~mm}$ anti-frogman system for use in littoral waters; however, this 'indigenous' system bears an uncanny resemblance to the Russian DP-65 anti-diver grenade launcher designed and sold by Russia's V.A. Degtyarev Plant. ${ }^{44}$ Also, China's local J-15 fighter is held to be comparable to the Sukhoi SU-33 carrier-capable fighter. ${ }^{45}$ Similarly, Moscow has protested that the PLA(A)'s development of the stealthy J-11B Thunderbird fighter was based on Russia's SU-27. ${ }^{46}$ Technological emulation is the objective of offset, but whilst most states strive for the absorptive capacity to make offset work, China already possesses it. Unsurprisingly, then, Chinese engineers have reverse-engineered SU-27SK fighter technologies to generate next-generation design modifications. This is evidenced by a recent report from the Moscow-based Center for the Analysis of Strategies and Technologies that argues the Chinese military has developed a modification of the SU-27SK engine, extending its operational life from 900 to 1,500 hours, and describing it as a noteworthy achievement in aerospace technology. ${ }^{47}$

Aided by China's undisclosed, but undisputedly high, levels of R\&D investment, the process of technological transformation has created the capacity for it to develop and produce high-end weapons systems for export to a growing and geographically diverse overseas customer base. China presently exports a broad array of modern military platforms and armaments to over fifty countries across the world. The Middle East, for instance, has become a target for Chinese arms exports, beyond acting as the traditional supplier of conventional military equipment to Iran, Saudi Arabia and Syria. As highlighted earlier, there are also growing numbers of African states becoming customers of China's competitive weapon systems. For instance, in 2014, China sold 24 light amphibious tanks and 12 120mm self-propelled mortar systems to Tanzania, ${ }^{48}$ 11 Armored Personnel Carriers (APCs) and 12 large caliber artillery systems to 
Cameroon; ${ }^{49}$ and in 2015, two patrol vessels were sold to the Cameroon Navy, partly funded by China's Export-Import (EXIM) Bank. ${ }^{50}$ The biggest potential African market is Nigeria, which is considering procuring 25-40 of the Sino-Pakistan collaborative JF-17 Thunder $4^{\text {th }}$-generation fighters. ${ }^{51}$ Already, the Nigerian navy is procuring two Chinese-built Offshore Patrol Vessels for combatting illegal fishing, arms proliferation, sea piracy and oil theft in the Gulf of Guinea. ${ }^{52}$ China will produce these OPVs, but, significantly, workers in Nigeria's fledgling shipbuilding industry will be allocated the low-value 'fixtures and fittings' (offset) work. ${ }^{53}$

China is also expanding its footprint in Latin America's arms market. Several strategies are being followed, including consolidating its position in existing country markets, prizing open new niche defense segments, and seizing opportunities in the Continent's emerging markets. Ecuador, for instance, is seeking to collaborate with China in the development and production of defense-related cyber-security models and satellite systems. ${ }^{54}$ Additionally, Chinese participation has been mooted in a joint Ecuadorian and Peruvian aeronautical program aimed at developing an aircraft through shared technology with Brazil, Venezuela and Argentina. ${ }^{55}$ In land systems, China is in the process of supplying over 700 different types of civil-military land vehicles, including multi-purpose trucks, fuel and water tankers, buses and tippers, in pursuit of ultimately ousting Quito's long-standing German and Spanish land systems suppliers. ${ }^{56}$ Additionally, China is actively courting another Latin American defense sales prospect, Argentina. A Memorandum of Understanding (MoU) on joint production of weapon systems was signed by the two nations in October 2014. The following year Argentina announced it would buy five Chinese designed Offshore Patrol Vessels. Controversially naming them the Malvinas Class, the first two of the series will reportedly be built in China, and the remaining three co-produced in Argentina. ${ }^{57}$ Argentina has already procured four Chinese wheeled Armored Personnel Vehicles (APVs) that were deployed to Haiti on peacekeeping operations, but the $2014 \mathrm{MoU}$ has led to a far more significant deal, whereby Buenos Aires will procure and locally assemble 110 wheeled APVs with amphibious war-fighting 
capability. ${ }^{58}$ Also linked to the MoU is a program to procure 20 Chinese JF-17 Thunder fighter jets produced by the Chengdu Aircraft Corporation. ${ }^{59}$ The deal comes after Argentina abandoned talks with Russia's Putin to purchase 12 ageing Sukhoi SU-24 'Fencer' bombers, and was then thwarted by the United Kingdom in its efforts to procure Swedish Gripen fighters via Brazil, because the aircraft contained $30 \%$ British parts. ${ }^{60}$ China's arms sales to Argentina are subject to Beijing's non-interference policy that ensures deals are not derailed by extraneous diplomatic issues. Yet, sometimes the pressures move the opposite way, with opposition to China's plan to construct a satellite ground station in Patagonia, Argentina, the first outside China's borders, coming from Argentinian critics, who believe that it will potentially endanger Argentina's national interest in the event of a Sino-US conflict. ${ }^{61}$

However, Asia is where Chinese arms have had the greatest impact, especially those client states geographically contiguous to arch foe, India. Pakistan, Bangladesh, Sri Lanka and Myanmar have all procured copious amounts of Chinese arms, with Beijing even offering an offset package to build a dockyard in the Maldives, one of India's key strategic allies in the Indian Ocean. ${ }^{62}$ As a means of gaining access to a market, the construction of ports is a well-tested Chinese strategy already employed in Myanmar (Sittwee), Sri Lanka (Hambantota) and Pakistan (Gwadar). ${ }^{63}$ Pakistan, in particular, is China's closest ally, arms purchaser and defense-industrial partner. In 2015, for instance, Islamabad agreed to procure eight Chinese Type 041 Yuan Class diesel-electric attack submarines, with $50 \%$ of them to be built in Karachi docks as part of an offset agreement incorporating technology transfer. ${ }^{64}$ China has also played an instrumental role in partnering with the Karachi Shipyard and Engineering Works in the fabrication of three Fast Attack Craft (Missile), building on the transfer of technology a decade earlier that enabled Pakistan to partially license produce Chinese F-22P Frigates. ${ }^{65}$ Similarly, in the aerospace sector, China is partnering with Pakistan in the joint development and production of, firstly, the J-17 fighter, with Islamabad planning procurement volumes of 275 units, ${ }^{66}$ and, secondly, the locally developed Burraq, an Unmanned Aerial Vehicle (UAV) that carries a strong resemblance to 
China's CH-3 UAV. ${ }^{67}$ Additionally, China is seeking to sell $30-40$ Shenyang FC-31 twin-engine stealth fighters to Pakistan. ${ }^{68}$

Chinese arms are proving equally attractive to an array of Southeast Asian states. In 2011, China signed a MoU with Indonesia on joint military procurement involving technology transfer, joint development and joint marketing of pre-determined weapons systems. ${ }^{69}$ These systems include C907 missiles, deployed on China's Sukhoi fighters, and thus can similarly be deployed on those already in service with Indonesia's air force. ${ }^{70}$ In addition, Indonesia signed a contract in March 2013 to locally produce China's C-705 anti-ship missiles, ${ }^{71}$ and more recently in 2014, Beijing and Jakarta reached agreement to undertake a joint feasibility study to assess procurement of China's SLR-66OTH maritime radar system. ${ }^{72}$ China offers an obvious supplier diversification strategy for Indonesia. Beijing's non-interference policy means it would never resort to arms embargoes, and this carries significant appeal to Jakarta, as resentment still lingers over America's six-year arms embargo imposed in 1999, following human rights concerns in East Timor. Fellow Southeast Asian state, Thailand, is also in the process of deepening its arms trading ties with China. As with most developing states, Thailand requires technology transfer to be linked to arms purchases, as a means of nurturing indigenous design and production capability. An example of this process is the development of a $122 \mathrm{~mm}$ Multiple Rocket Launcher (MRL) by Thailand's Defence Technology Institute (DTi). The MRL, known locally as DTi-2, is an indigenous system that evolved from earlier Chinese MRL systems, procured in 2009 and produced in Thailand through technology transfer via offset arrangements. ${ }^{73}$ Offset is also likely an element in Thailand's 2015 procurement of three Chinese Yuan-Class (Type 041) submarines, the same as those presently under order by Pakistan. ${ }^{74}$

\section{Reputational damage-control through export constraints}

As long ago as 1987, China introduced legislation (Control of Nuclear Materials) that initiated the gradual development of an arms control regime. A cautious approach was 
adopted, seeking to carefully balance domestic decision-making autonomy with external, essentially Western, arms control pressures and requirements. It has been a challenging process for two reasons: firstly, the sheer size of China's trading economy (370,000 companies, of which $70 \%$ are private-owned) means that even though only a small proportion of firms engage in proliferation-sensitive trade, it still represents a significant minority of businesses requiring monitoring in order to prevent illegal export; and, secondly, the PLA's military culture and dominant role in China's political and commercial spheres has provided it with the opportunity to delay enforcement, or even circumvent, China's export control policy. ${ }^{75}$ Indeed, China's arms exporting companies may be beyond the control of government. ${ }^{76}$ At times, this has appeared alarmingly evident. For instance, in 1996 some 2,000 Chinese-made AK-47 assault rifles were seized in California, seemingly as part of a smuggling racket organized by two of China's flagship armament companies. ${ }^{77}$ In 2011 , China was again embarrassed by revelations that representatives of some of China's biggest defense contractors had met with officials of Libya's internationally ostracized Gaddafi regime in contravention of the UN embargo, and without the knowledge of the Chinese government. ${ }^{78}$

Such lapses in China's arms export control regulations make for good newspaper copy, but ignore the institutional panoply of arms constraints covering nuclear, biological, chemical, missile and other military and dual-use systems. The controls are structured under three tiers of export controls: 1) national laws formulated by the National People's Congress, 2) regulations agreed by the Chinese State Council - the top administrative organ of the Government, and 3) ministerial decrees formulated by separate ministries, including those of Commerce (MofCom), Industry and Information Technology (MIIT), Atomic Energy (CAEA) and Foreign Affairs (MFA). ${ }^{79}$ In addition, there are two laws that provide the legal basis for implementing China's export controls, namely, the 1994 Foreign Trade Law and the 1987 Customs Law (revised in 2000). Whilst there are permanent export control lists of excluded items, it is also possible to introduce temporary ad hoc measures, such as the 2006 
export license requirement for exports of graphite related products. ${ }^{80}$ Beijing acknowledges that deficiencies remain in its export control regime, and need to be addressed in order to comply with both UN Security Council resolutions and to protect China's international reputation. Part of this policy-strengthening process has fallen to the Ministry of Foreign Affairs. It has been tasked with drafting a new two-level non-proliferation law that will address higher-level strategic non-proliferation challenges, such as non-state actors. Additionally, a novel 'all process control' concept will be introduced to monitor listed technologies, from R\&D to manufacturing, transportation, exporting and shipment, with the intention of exerting control over the entire life cycle of proliferation-sensitive products. ${ }^{81}$

\section{Conclusions}

China is a global industrial and technological heavyweight, yet its rise to power has been tardy, thwarted by internal and external conflict, ideological distraction and command economy dogma. Deng Xiaoping's 1978 'Open door' policy heralded a long period of political stability and robust economic growth through promotion of a capitalist incentivization framework, creating the conditions for substantial and ongoing expansion in defense spending. The accompanying desire to close the technology gap with the West led to accelerated deepening of military capability. China's resulting defense economic strength meant that it was positioned through the 2001 'going-out' strategy to pursue an economic diplomacy policy that sought influence through foreign aid, foreign direct investment and foreign military sales.

A strong global economic diplomacy platform was constructed enabling overseas arms sales to both support and be supported by foreign policy. The result is that since the early 2000s, China has dramatically expanded its arms trade, exporting to 55 countries across Asia, the Middle East, Africa and Latin America. Although its share of international sales is small, at just below 7\% in 2015, China is now firmly established as one of the world's leading arms exporters. The country's success has been achieved by emphasizing economic value, including low upfront and through-life costs and the provision of acceptable technical quality, as well as a political disinclination to interfere in the domestic policies of arms purchasing states. 
China's success has traditionally been forged through sales of low-tech weapons, but this now appears to be changing as the value proposition is enhanced. Arms export competitiveness now embraces higher levels of technology and an apparent preparedness to partner and transfer rising levels of that technology. This approach is likely to prove successful in both consolidating existing market positions amongst the emerging nations and penetrating the new markets of higher income states. 'Made in China' is developing into a brand that not only sells weapons on the world stage but expands foreign policy influence through economic diplomacy.

\section{Notes}

1 D. Nissenbaum, 'Pentagon Lays Out Challenge Posed by China's Growing Military Might', Wall Street Journal, 6 June, 2014,

http://www.wsj.com/articles/pentagon-lays-out-challenge-posed-by-chinas-growing-military-might-140 2005458 (Accessed 10 August 2016).

2 From SIPRI Arms transfer Database. China’s exports were US\$ 302 million at constant (1990) prices in 2000, and US\$ 1,966million in 2015. http://armstrade.sipri.org/armstrade/page/values.php,

(Accessed 6 August 2016).

${ }^{3}$ From SIPRI Arms transfer Database. http://armstrade.sipri.org/armstrade/page/values.php, (Accessed 6 August 2016)

${ }^{4}$ For a detailed evaluation of China's approach towards developing systems integration using a case study of warships, see, M. Clemens et al, 'The Type 054/054A Frigate Series: China's most Produced and Deployed Large Surface Modern Combatant', China Signpost, 2 August 2015, http://www.chinasignpost.com/2015/08/02/the-type-054054a-frigate-series-chinas-most-produced-anddeployed-large-modern-surface-combatant/ (Accessed 10 August, 2016)

5 Ashley Cowburn, 'Two thirds of African countries now using Chinese military equipment, report reveals', Independent, 1 March, 2016.

http://www.independent.co.uk/news/world/africa/two-thirds-of-african-countries-now-using-chinese-mi litary-equipment-a6905286.html (Accessed 5 August, 2016)

${ }^{6}$ Richard A. Bitzinger, Chinese Arms Production and Sales to the Third World, Rand, 1991, 1. http://www.rand.org/content/dam/rand/pubs/notes/2009/N3334.pdf, (Accessed 1 October 2015).

7 See, for instance, 'The New Colonialists', The Economist ,13 May, 2006; Robert Sutter, China's

Foreign Relations: Power and Policy since the Cold War, Lanham, MD: Rowman \& Littlefield, 2008;

Samuel J. Spiegel and Philippe Le Billon, 'China's weapons trade: from ships of shame to the ethics of global resistance', International Affairs, 85/ 2, 2009, 323-346.

${ }^{8}$ Indra de Soysa and Paul Midford, 'Enter the Dragon! An Empirical Analysis of Chinese versus US Arms Transfers to Autocrats and Violators of Human Rights 1989-2006', International Studies Quarterly, 2012, 56, 843-856.

9 Ibid., 853.

${ }^{10}$ Country categories derive from the World Bank database, 2014.

${ }^{11}$ Unless, otherwise stated, all data cited in this section derives from SIPRI International Arms Transfer Database, based on 1990 US\$ million constant prices, and accessed 4 August 2015.

12 Richard A. Bitzinger, Chinese Arms Production and Sales to the Third World, Rand, 1991, p3, http://www.rand.org/content/dam/rand/pubs/notes/2009/N3334.pdf, (Accessed 1 October 2015).

${ }_{13}$ Deng Xiaopin: We have to abandon the idea of "Never to be an arms merchandiser", http://news.xinhuanet.com/mil/2011-04/14/c 121305081.htm, (Accessed 16 August 2016).

${ }_{14}$ The First Deal of Chinese Arms Export, http://mil.news.sina.com.cn/2011-02-27/1603634976.html (Accessed 1 October 2015). 
${ }^{15}$ Ashley Cowburn, 'Two thirds of African countries now using Chinese military equipment, report reveals', Independent, 1 March, 2016.

http://www.independent.co.uk/news/world/africa/two-thirds-of-african-countries-now-using-chinese-mi litary-equipment-a6905286.html (Accessed 5 August, 2016)

${ }^{16}$ Regulations on Export Control of Military Items of the People's Republic of China, Article 5. http://en.people.cn/200601/12/eng20060112_234894.html, (Accessed 1 October 2015).

${ }^{17}$ China's African Policy, 2006, http://www.gov.cn/misc/2006-01/12/content_156490.htm, (Accessed 1 October 2015).

${ }^{18}$ Report to the Seventeenth National Congress of the Communist Party of China, 2007. http://news.xinhuanet.com/newscenter/2007-10/24/content_6938568.htm. The Five Principles of Peaceful Coexistence are mutual respect for sovereignty and territorial integrity, mutual non-aggression, non- interference in each other's internal affairs, equality and mutual benefit, and peaceful coexistence. http://en.people.cn/92824/92845/92870/6441502.html, (Accessed 7 September 2015).

${ }_{19}$ Report to the Seventeenth National Congress of the Communist Party of China, 2007, http://news.xinhuanet.com/newscenter/2007-10/24/content_6938568.htm

20 National Council's Guidelines for Reducing the Oversupply and Reliving the Inconsistency between Demand and Supply. http://politics.people.com.cn/n/2013/1015/c1001-23210728.html, (Accessed 2 October 2015).

${ }^{21}$ Mark Bromley, Mathieu Duchatel and Paul Holtom, 'China's Exports of Small Arms and Light Weapons', SIPRI Policy Paper, 38, October 2013, 37.

${ }_{22}$ Meredith Lauren Blank, Hugging with Tactical Arms: What Motivates China to Export Weapons? (degree Thesis - The University of Michigan), 2009, 121.

https://deepblue.lib.umich.edu/bitstream/handle/2027.42/63929/blank_meredith_2009.pdf;sequence=1 (Accessed 7 September 2015).

${ }^{23}$ Jijo Jacob, 'The Chinese Model: Arm the World at a Discount', International Business Times, 21 October, 2013.

${ }^{24}$ Katharina Hofmann, Jurgen Kretz, Michael Roll and Sebastian Sperling, Contrasting Perceptions: Chinese, African, and European Perspectives on the China-Africa Summit, 2007,78, http://www2.china-europa-forum.net/bdfdoc-1567_zh.html (Accessed11 August, 2016).

${ }_{25}$ Alexander Lennon, 'Trading guns, not butter', China Business Review, Vol. 21 Issue 2, Mar/April 1994, 47-49.

${ }^{26}$ Mark Bromley, Mathieu Duchatel and Paul Holtom, 'China's Exports of Small Arms and Light Weapons', SIPRI Policy Paper, 2013, October 2013, p.38.The authors agree that China's arms sales benefit from the fact that many states are seeking to diversify sources of supply, and China remains one of the most likely sources for states seeking low-cost small arms and light weapons.

27 Andrew Hull and David Markov, Chinese Arms Sales to Africa, 2012, 29.

https://www.ida.org/ /media/Corporate/Files/Publications/ResearchNotes/RN2012/2012\%20Chinese\% 20Arms\%20Sales\%20To\%20Africa.pdf (Accessed11 August, 2016).

GuoSilu, Liu kaiqi, 'Chinese Arms Exports: A Lonely Business', South Weekend, 2013

Jijo Jacob, 'The Chinese Model: Arm the World at a Discount', International Business Times, 21

October, 2013; 'China Defence and Security Report', Business Monitor International, 2014.

${ }^{28}$ Chinese workers' average annual salary in 2014 was 49,969 Yuan.

http://finance.chinanews.com/life/2015/06-16/7345851.shtml. The RMB exchange rate with US\$ was 6.119 on 31st December, 2014, and the RMB to the Pound was 9.5437.

http://www.mofcom.gov.cn/article/i/jshz/rlzykf/201412/20141200854769.shtml, (Accessed 7 August 2016). American nonfarm real average hourly salary in June 2014 was $\$ 10.31$, sourced from REAL EARNINGS - JUNE 2015, Bureau of Labor Statistics U.S. Department of Labor. The UK's average annual earnings figure in 2012 was $£ 26,500$ : 'Average earnings rise by $1.4 \%$ to $£ 26,500$, says ONS', http://www.bbc.co.uk/news/business-20442666 (Accessed 5 August, 2016).

${ }^{29}$ Joseph E. Lin, China's Weapons of Mass Consumption, 20 March, 2015:

http://foreignpolicy.com/2015/03/20/chinas-weapons-of-mass-consumption/ (Accessed 11 August, 2016).

${ }^{30}$ Daniel Southerl, 'China Boosts Arms Sales in Mideast', The Washington Post, 4 April, 1988. http://www.washingtonpost.com/archive/politics/1988/04/04/china-boosts-arms-sales-in-mideast/6ec82 9a4-99c8-4de9-88b1-cd44760605c5/, (Accessed 7 September 2015).

${ }^{31}$ Shai Oster, 'China's New Export: Military in a Box', Bloomberg Businessweek, 25 September, 2014.

${ }^{32}$ See, Daniel Byman and Roger Cliff, China's Arms Sales: Motivations and Implications, Rand ,1999, 22; Shai Oster, 'China's New Export: Military in a Box', Bloomberg Businessweek, 25 September, 2014, and Robert Wall and Andy Nativi, 'China Shop', Aviation Week \& Space Technology, 172/41, 2010, 67 
33 Joseph E. Lin, China's Weapons of Mass Consumption, Foreign Policy, 20 March, 2015, http://foreignpolicy.com/2015/03/20/chinas-weapons-of-mass-consumption/ (Accessed 11 August, 2016).

${ }^{34}$ L. Sariibrahimoglu, 'Turkey Advances TFX Fighter Project, Orders New Rifles, More F-35s, CH-47s', IHS Jane's Defence Weekly, 8 January 2015.

35 'Turkey's selection of Chinese SAMs viewed as 'stepping stone' to Europe', Jane's Defence Weekly, 30 September, 2013.

${ }^{36}$ Christopher Bodeen, 'Study: China has grown to world's $3^{\text {rd }}$-biggest arms exporter', Military.com, 17 March 2015.

http://www.military.com/daily-news/2015/03/17/study-china-has-grown-to-worlds-3rd-biggest-arms-ex porter.html (Accessed 5 August 2016).

37 Joseph E. Lin, China's Weapons of Mass Consumption, Foreign Policy, 20 March, 2015, http://foreignpolicy.com/2015/03/20/chinas-weapons-of-mass-consumption/ (Accessed 11 August, 2016).

${ }^{38}$ Ibid.

${ }^{39}$ Ibid

${ }^{40}$ Robert Wall and Andy Nativi, 'China Shop', Aviation Week \& Space Technology, 172/ 41, 2010, 67. http://support.ebsco.com/help/?int=eds\&lang=\&feature_id=Harvard (Accessed 11 August, 2016). ${ }^{41}$ Ibid.

${ }^{42}$ Joseph E. Lin, China's Weapons of Mass Consumption, Foreign Policy, 20 March, 2015. http://foreignpolicy.com/2015/03/20/chinas-weapons-of-mass-consumption/ (Accessed 11 August, 2016).

${ }^{43}$ Daniel Byman and Roger Cliff, China's Arms Sales Motivations and Implications, Rand, 1999, and GuoSilu, Liu kaiqi, 'Chinese Arms Exports: a Lonely Business', South Weekend, 2013, http://www.infzm.com/content/95739 (Accessed 7 September 2015).

${ }^{44}$ R. Johnson, 'Russian Firms Look to Boost Business with China', IHS Jane’s Defence Weekly, 9 October, 2014.

45 Ibid.

${ }^{46}$ Reuben Johnson, 'China Builds its Own Hi-Tech Military', Washington Times, 22 September 2010. http://www.washingtontimes.com/news/2010/sep/21/china-builds-its-own-high-tech-military/

(Accessed 11 August, 2016).

${ }^{47}$ Ibid.

${ }^{48}$ Jeremy Binnie, 'UN Documents Shed Light on African Defence Procurement', IHS Jane's Defence Weekly, 12 October 2014.

${ }^{49}$ Ibid.

${ }^{50}$ Jeremy Binnie, 'Cameroon Takes Delivery of Chinese Patrol Boats', IHS Jane’s Defence Weekly, 28 January 2015.

${ }^{51}$ Farhan Bokhari, 'IDEAS 2014: Nigeria 'Close to Signing Up' for JF-17', IHS Jane's Defence Weekly, 2 December 2014.

52 Jude Okwe, 'Nigerian Navy Imports Two Warships from China', All Africa, 9 December 2013,

${ }^{53}$ Chiemelie Ezeobi, 'Navy Warship Arrives Nigeria from China', All Africa, 9 February 2015.

54 'Equador to Develop its Own Satellite with Chinese Help', 18 September, 2014.

http://www.panamericanworld.com/en/article/ecuador-develop-its-own-satellite-chinese-help (Accessd 11 August, 2016).

55 Ibid.

${ }^{56}$ I. Guevara, 'Truck Delivery Highlights Rekindled Sino-Ecuadorian Relations', IHS Jane's International Defence Review, 29 April 2015.

${ }^{57}$ R. Fisher, 'China, Argentina Set for Defence Collaboration, Malvinas-Class OPV Deal', IHS Jane's Defence Weekly, 1 February 2015.

58 'Argentina to Buy 110 VN-1 Armored Personnel Vehicles From China, 17 June 2015. https://

Venezuela has also procured the same APC model from China, see R. Fisher, 'Venezuela Signs Up for VN1, Hints at Chinese Amphibious Vehicles Buy', IHS Jane's Defence Weekly, 23 November 2014.

${ }^{59}$ M. Giannangeli, 'China Sells Fighter Jets to Argentina which are able to attack Falkland Islands', 15 February 2015.

http://www.express.co.uk/news/uk/558226/China-Argentina-falkland-islands-fighter-jets (Accessed 11 August, 2016).

${ }^{60}$ Ibid.

${ }^{61}$ Uki Goni, ‘Argentinian Congress Approves Deal with China on Satellite Space Station', Guardian 27 February 2015. 
https://www.theguardian.com/world/2015/feb/26/argentina-congress-china-satellite-space-station (Accessed 11 August, 2016)

62 'Army Chief in Maldives to Push Dockyard Project', Deccan Herald, 9 May 2014.

${ }^{63}$ Ibid.

${ }^{64}$ F. Bokhari et al, 'Pakistan in Talks with China 'for Eight Submarines", IHS Jane's Navy International, 31 March 2015, and 'China to Build Four Submarines in Pakistan's Karachi', BBC Monitoring South Asia, 7 October 2015.

${ }^{65}$ 'China to Transfer Technology: F-22P Frigates', Hindustan Times, 7 April 2005.

${ }^{66}$ R. Fisher, 'Paris Air Show 2015: JF-17 Fighter with Indigenous Chinese Turbofan', IHS Jane's Defence Weekly, 17 June 2015.

67 'Pakistan Air Force Denies China Helped Military Acquire Armed Drones', Daily Messenger, 8 October 2015.

${ }^{68}$ Ibid.

69 'Indonesia, China to begin Arms Production Partnership', BBC Monitoring Asia Pacific, 23 March 2011.

${ }^{70}$ Ibid.

${ }^{71}$ Kate Lamb, 'Indonesia, China to Sign Missile Production Agreement', Voice of America Press Releases and Documents, 16 August 2012.

http://www.voanews.com/content/indonesia_and_china_to_sign_missile_production_agreement/14896 59.html (Accessed 11 August, 2016).

72 'Indonesia, China Agree to Review Maritime Radar Procurement', Selasa, 23 September 2014. http://www.republika.co.id/indeks/hot topic/purnomo yusgiantoro (Accessed 11 August, 2016).

73 Jon Grevatt, 'Thailand to Continue Development of 122mm MRL System', IHS Jane's Defence Industry, 10 December 2014.

${ }^{74}$ Jon Grevatt, 'Royal Thai Navy Announces Plan to Buy Chinese Yuan-Class Submarines', IHS Jane's Navy International, 2 July 2015.

75 James R. Holmes, 'Military Culture and Chinese Export Controls', The Nonproliferation Review, 12/3, 2005, 473-502.

${ }^{76}$ Colum Lynch, 'China's arms exports flooding sub-Saharan Africa', The Washington Post, August 25, 2012.

https://www.washingtonpost.com/world/national-security/chinas-arms-exports-flooding-sub-saharan-af rica/2012/08/25/16267b68-e7f1-11e1-936a-b801f1abab19 story.html (Accessed 11 August, 2016).

${ }_{77}$ B. Gilley et al, 'Security - Guns and Money: Illicit Arms Trade Puts China on the Defensive', Far Eastern Economic Review, 6 June 1996.

78 'China at Risk of Losing Out to the NTC's Western Allies after Gaddafi Arms Deal Reservations', International Business Times, 6 September 2011.

http://www.ibtimes.co.uk/china-at-risk-of-losing-out-to-the-ntc-s-western-allies-after-gaddafi-arms-dea 1-revelations-209272 (Accessed 11 August, 2016).

${ }^{79}$ Xiaoming Liu, 'Upgrading to a New, Rigorous System', RUSI Occasional Paper, March 2016, 4.

${ }^{80}$ Ibid., 15.

${ }^{81}$ Ibid., 17. 


\section{Acknowledgements}

We wish to thank Dr Collin Koh Swee Lean, RSIS, Nanyang Technological University, Singapore, for invaluable research support.

\section{Disclosure statement}

No potential conflicts of interest were reported by the authors. 